\title{
Daniel A. Robert
}

Recognizing the Gift: Toward a Renewed Theology of Nature and Grace. Minneapolis: Fortress Press 2016. Pp. 278. Hb, \$79.

In a recent addition to the Emerging Scholars dissertation series in theology, Daniel Rober retraces a fault line debate about the relationship between nature and grace in twentieth-century Catholic theology to renew its phenomenological import and uncover its political implications. Rober believes that this classic debate has stalled in some ways and needs to be jumpstarted with a phenomenological and political perspective. Rober takes the reader on an impressive tour of theological and philosophical luminaries to light up a path toward renewal in contemporary theological debates.

For Rober, the relationship between nature and grace remains just as relevant today as it was in the twentieth century, however in a religiously diverse age "it is inevitably difficult to persuade people that their deepest desires are ultimately for grace" (216) - especially people in situations of oppression. To remedy this problem, Rober suggests that a new, politically focused hermeneutic is required to make the proper connection between nature and grace. To arrive at the details of this new hermeneutic, Rober takes the reader on a tour of important thinkers over the past fifty years to show how discussions of nature and grace have migrated back and forth across the boundaries of theology and phenomenology.

Building upon the foundational insights of Henri de Lubac and Karl Rahner, Rober turns to Hans Urs von Balthasar in search of an ontology to support an adequate political theology of nature and grace. Rober finds an important clue in Balthasar's positive treatment of liberation theology and examines the legacy of liberation theologians like Gustavo Gutiérrez to connect their treatment of "gift" with the previous discussion of de Lubac and Rahner, highlighting the contours of continuity and development. Then Rober infuses a complementary account of "gift" and "recognition" from the phenomenological writings of Jean-Luc Marion and Paul Ricoeur. This allows Rober to conclude this aerial tour by introducing the work of Kathryn Tanner and John Milbank who are in conversation with Marion and Ricoeur, for a more adequate turn toward the political in contemporary debates about nature and grace.

Although the terrain covered in this book is vast and exciting, the landscape of the book could have benefitted from a more focused and sustained reading of the representative group of authors. Often Rober's insightful stance on a given theme in an author's work risks being missed as a passing observation. For example at the end of his chapter on Marion, Rober suggests that since Marion 
uses the word "capax" in his reflections on Descartes, there is a clear dependence upon de Lubac (132). This is a remarkable observation that could have appeared at the start of the chapter and the rest of the chapter could have been dedicated to explaining why this is significant for the overall argument of the book. At times, Rober's thematic treatment of various thinkers stops abruptly and it can leave the reader searching for how the central argument of the book illuminates all the moving pieces in a coherent way. The closest one comes to recognizing the book's central argument is in its title; but this must be pointed out to the reader: "I will argue for a theology of nature and grace construed in terms of recognizing the gift" (xvi). Constant reference is made throughout to an author's view of nature and grace, but Rober often does not explain what specifically a given thinker contributes to the advancement of this debate, or how the thinker specifically provides the missing political component. Perhaps a sharper focus on a smaller group of representative thinkers could firm up the concrete ressourcement connections between de Lubac, Gutiérrez, Marion, and Ricoeur (who individually get the terms "grace," "political," "gift," and "recognition" out on the table). Then the reader could be shown how these treatments can be used to advance contemporary discussions in political theology. Nevertheless, readers interested in phenomenology and the topic of nature and grace should find an illuminating companion with Rober's unique book.

\author{
Joshua Furnal \\ Radboud University \\ j.furnal@ftr.ru.nl \\ DOI 10.1163/22141332-00403007-22
}

